can be expected from the cultivation of rose geranium as a money crop. The costs of producing this crop have not been accurately worked out, since no commercial plantings were attempted, and it appears extremely doubtful if any net profit could be expected when the gross returns are so small.

\title{
THE CHEMISTRY OF THE HEPTANE SOLUTION.
}

BY EDWARD KREMERS.

4. THE HYDROHALOGENS.

(Continued from December Number, p. 1163.)

BY D. C. L. SHERK.

Preparation and Properties of the Solutions.-In this work heptane which had been specifically purified by the hydrohalogens was used. For solutions of hydrogen fluoride, chloride and bromide the heptane purified by hydrogen chloride was used; for the solution of hydrogen iodide that purified by iodine or hydrogen iodide was used.

First a solution was prepared and the strength determined. This was then used for later experimental work in testing the reactivity of the solutions. Solubility determinations of the gases in heptane were made for a series of temperature intervals from $0^{\circ}$ to $40^{\circ}$. Small portions of the purified heptane were saturated with the respective gases and the hydrohalogen titrated in these solutions directly. The vessels for the solubility determinations were light globes with a somewhat drawn out neck. Through this narrow neck a capillary tube dipped into the heptane filling the bulb. A slow stream of gas was passed through the weighed bulb for a half hour until saturation was complete. The bulb was then quickly sealed and weighed, after temperature adjustments had taken place. The bulb was broken under alkali solution in a large wide-mouth glass-stoppered bottle.

1. Hydrogen Fluoride Solution.-The gas was prepared by warming a mixture of calcium fluoride with two equivalents of sulphuric acid in a copper vessel. The gas was contaminated with a slight trace of sulphur dioxide from the action on the metal.

The solution was prepared by conducting the gas, after drying by bubbling through sulphuric acid, directly into the heptane. The solution obtained in this way was used in testing the action on metals. In the attempt to obtain large evolutions of gas more sulphur dioxide became mixed and accordingly no saturated solutions were prepared and no solubility determinations were made at this point. The solution assayed about 0.05 percent acid. This solution fumed strongly in air and kept well in glass-stoppered vessels. There was no appreciable action on the glass; although there was a tendency to wet the glass unequally.

2. Hydrogen Chloride Solution.-The gas was prepared by the action of sulphuric acid on ammonium chloride in a Kipp generator. The gas was passed through sulphuric acid to remove acid spray and dried by a phosphorus pentoxide tube about $40 \mathrm{~cm}$. long. This tube was filled with alternate layers of glass wool covered with the drying agent, the phosphorus pentoxide. Before the gas entered the 
heptane it was bubbled through a wash bottle containing a thin layer of heptane in which was suspended phosphorus pentoxide. The heptane was saturated at about room temperature and this solution used for the preliminary testing of its action on the metals.

For the solubility determinations, small bulbs were set up in a train and saturated at the desired temperature. For a determination at $0^{\circ}$ ice was packed around the bulbs and stirred frequently. The gas was passed for one-half hour or so and check determinations were obtained. The sealed bulb was allowed to come to room temperature before weighing. These bulbs were very thin and were entirely filled with heptane. To reduce as much as possible the dead space above the liquid in which at higher temperatures the concentration of the gas was greater than in the solution, the necks were long drawn out and the seal made as close as possible to the bulb. In this way the air space never amounted to more than a fraction of a cubic centimeter; while the bulbs were made proportionally large for slight solubilities and high temperatures. A thermostat regulating to within $0.1^{\circ}$ was used for the other temperatures.

The solution fumes strongly in air and takes up moisture which appears first as a turbid, milky layer on the top. Finally, the solution becomes clear and a layer forms at the bottom which is, of course, a saturated solution of aqueous hydrochloric acid in equilibrium with the heptane-hydrogen chloride solution. A preliminary study of the distribution was made.

Solubility of Hydrogen Chloride in Heptane.-At $0^{\circ}$ (I) 8.615 grammes solution, (II) 15.168 grammes, and (III) 10.546 grammes required of $0.1 \mathrm{~N}-\mathrm{NaOH}$ (I) $22.64 \mathrm{Cc}$, (II) $40.25 \mathrm{Cc}$, and (III) $28.34 \mathrm{Cc}$.

$$
\begin{aligned}
& 0^{\circ}-1 \mathrm{Gm} \text {. solution requires } 2.668 \mathrm{Cc} .0 .1 \mathrm{~N}-\mathrm{NaOH}=0.973 \text { p. c. } \\
& 20^{\circ}-1 \mathrm{Gm} \text {. solution requires } 1.708 \mathrm{Cc} .0 .1 \mathrm{~N}-\mathrm{NaOH}=0.622 \text { p. c. } \\
& 40^{\circ}-1 \mathrm{Gm} \text {. solution requires } 0.283 \mathrm{Cc} .0 .1 \mathrm{~N}-\mathrm{NaOH}=0.103 \text { p. c. }
\end{aligned}
$$

Distribution of Hydrogen Chloride between Water and Heptane.-The temperature was kept constant at $25^{\circ}$ by means of a thermostat regulating to within $0.1^{\circ}$. The strength of the hydrogen chloride in the heptane was 0.00357 gramme per Cc.

The coefficient of distribution $=\frac{\text { Concentration in water }}{\text { Concentration in heptane }}$.

$100 \mathrm{Cc}$. heptane and $10 \mathrm{Cc}$. water taken. The entire heptane solution was titrated; while only $5 \mathrm{Cc}$. of the water were taken. $1 \mathrm{Cc}$. heptane required 0.00455 Cc. $0.1 \mathrm{~N}-\mathrm{NaOH}$ and $1 \mathrm{Cc}$. water required $6.902 \mathrm{Cc}$.

The coefficient of distribution is 1520 .

Conductance of Hydrogen Chloride in Heptane.-Measurements were made at $25^{\circ} \mathrm{C}$. in a bath the temperature of which was accurately controlled. The cell constant was obtained by determining the resistance of a solution $\left(\frac{N}{50}\right)$ of potassium chloride using water, distilled from barium hydroxide and condensed in tin, which had a conductance of $3.6 \times 10^{-6}$. The potassium chloride was dried thoroughly and the water was stored in "aged" flasks.

The heptane used was standing over sodium and poured off into the cell. For the solution of hydrogen chloride the heptane was poured off sodium and was saturated with the gas at about $18^{\circ}$. The gas was passed through sulphuric 
acid and over a layer of phosphorus pentoxide with glass wool in a tube about $40 \mathrm{~cm}$. long. The exit tube was protected by a short phosphorus pentoxide tube.

The solution was transferred to the interior of the conductivity cell by pressure and the latter closed by a ground stopper carrying sealed-in electrodes. The solution was thus saturated at $25^{\circ}$ after coming up to the temperature of the bath.

Measurements of resistance were made on a box giving direct readings and several portions of solutions were taken to obtain concordant values.

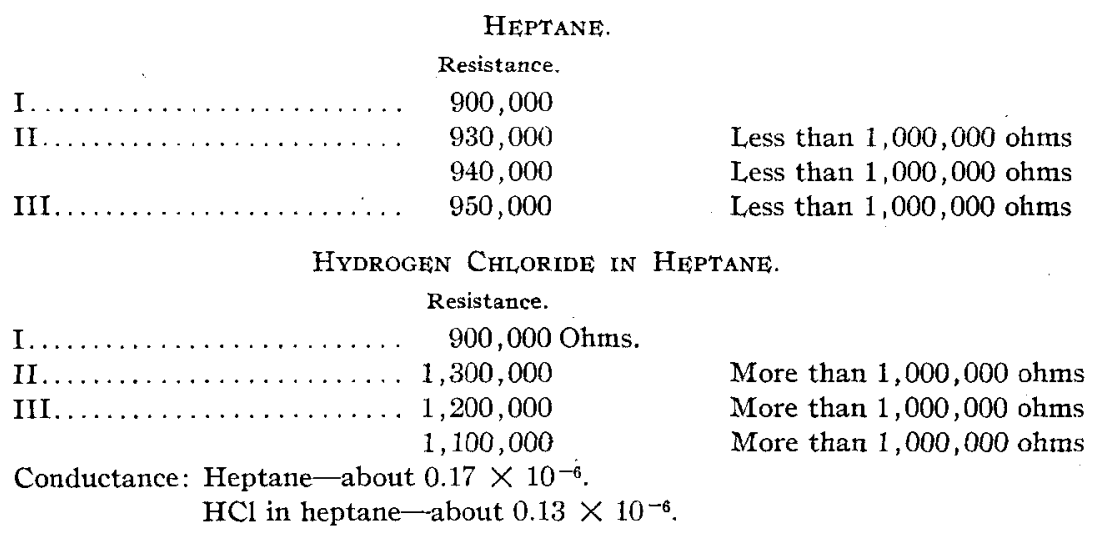

The magnitude of these two quantities is of the same order. There is very little difference between the pure solvent and the solution, the strength of which is about $6 / 10$ p. c. The experimental method would scarcely allow of a closer approximation in resistance between the solvent and solution.

3. Hydrogen Bromide Solution.-The gas was generated by allowing bromine to drop upon moist red phosphorus. It was purified by passing through a tube packed with red phosphorus and glass wool moistened with the concentrated hydrobromic acid. Next it was passed through a phosphorus pentoxide tube $35 \mathrm{~cm}$. long with the drying agent distributed over glass wool, and finally through a layer of heptane containing suspended pentoxide. The heptane saturated at this time had been purified by hydrogen chloride. The solution lost gas on rising to room temperature and was used at once for the preliminary work on the action of this solution on metals.

Solubility determinations were made in the usual manner except that for the higher temperatures the gas was obtained by warming a heptane solution and passing this evolved gas through the absorption bulbs. This was found to be a much more convenient method and delivered an anhydrous gas under perfect control.

Solubility.-At $0^{\circ}$ (I) 8.948 grammes solution, (II) 17.673 grammes, and (III) 11.591 grammes required of one-tenth normal $\mathrm{NaOH}$, (I) $55.69 \mathrm{Cc}$, (II) 69.78 Cc., and (III) $111.46 \mathrm{Cc}$, respectively.

$$
\begin{aligned}
& \text { At } 0^{\circ}-1 \mathrm{Gm} \text {. solution required } 6.267 \mathrm{Cc} .0 .1 \mathrm{~N}-\mathrm{NaOH}=5.06 \mathrm{p} . \mathrm{c} . \\
& \text { At } 20^{\circ}-1 \mathrm{Gm} \text {. solution required } 4.442 \mathrm{Cc} .0 .1 \mathrm{~N}-\mathrm{NaOH}=3.57 \mathrm{p} . \mathrm{c} . \\
& \text { At } 40^{\circ}-1 \mathrm{Gm} \text {. solution required } 1.534 \mathrm{Cc} .0 .1 \mathrm{~N}-\mathrm{NaOH}=1.25 \mathrm{p} . \mathrm{c} .
\end{aligned}
$$

4. Hydrogen Iodide Solution-Considerable difficulty was experienced in obtaining a solution of this acid which would contain no admixed iodine or would 
not decompose during absorption. The difficulty was partially overcome by using a dilute solution of the gas as a source of hydrogen iodide.

Hydrogen iodide was prepared by allowing a solution of iodine in hydriodic acid to pass into a flask containing red phosphorus moistened with hydriodic acid. ${ }^{1}$ This gas was passed through a U-tube containing moist red phosphorus, a drying tube of phosphorus pentoxide about $60 \mathrm{~cm}$. long and through a layer of heptane containing the pentoxide in suspension. In this manner a solution of the purified gas was obtained by absorbing it in heptane. The heptane always turned slightly turbid and as soon as this turbidity disappeared, the pink color of free iodine was noticed. 'This color reaches a maximum almost at once. The color is distinctive but never intense and the solution may stand for days even in sunlight without increasing appreciably. The solution fumes strongly in air and becomes turbid when exposed even for pouring.

Such solutions were used as a source of the gas for solubility determination and other experimental, work. The usual small bulbs were saturated by passing the gas under carefully controlled temperature. These solutions showed only the faintest pink color at first.

Solubility.-At $0^{\circ}$ (I) 7.267 grammes of solution and (II) 4.220 grammes required of one-tenth normal- $\mathrm{NaOH}$ (I) $132.0 \mathrm{Cc}$, and (II) $77.2 \mathrm{Cc}$, respectively. This corresponds to (I) 23.25 and (II) 23.38 percent hydrogen iodide.

$$
\begin{aligned}
& \text { At } 0^{\circ}-1 \text { gramme required } 16.05 \mathrm{Cc} .0 .1 \mathrm{~N}-\mathrm{NaOH}=23.32 \mathrm{p} . \mathrm{c} \text {. } \\
& \text { At } 20^{\circ}-1 \text { gramme required } 11.80 \mathrm{Cc} .0 .1 \mathrm{~N}-\mathrm{NaOH}=15.31 \mathrm{p} . \mathrm{c} . \\
& \text { At } 40^{\circ}-1 \text { gramme required } 7.17 \mathrm{Cc} .0 .1 \mathrm{~N}-\mathrm{NaOH}=9.22 \mathrm{p} . \mathrm{c} \text {. }
\end{aligned}
$$

- The density of the hydrogen iodide solution at $25^{\circ}$ is 0.779 .

The results show that the solubility of the hydrohalogens increase for the chloride, bromide, iodide. The solubility of this latter is very much in excess of that of the others.

The Action of the Hydrohalogens on Metallic and Non-metallic Elements.The solutions used for these tests were prepared in the manner explained previously, by saturating directly with the gas. They were titrated so that the strength of each was known, and with the exception of hydrogen fluoride which was very weak, the concentrations were somewhat near each other. The hydrogen iodide was prepared weak, and used as quickly as possible to avoid the decomposition with liberation of iodine and the uncertainty which the presence of this element would introduce.

Tests were carried out on the metals in different commercial forms and of different degrees of purity. About five grammes or so were placed in tubes closed with cork stoppers and the action noted. Wherever practicable the metal was cleaned before the test, and thus fresh surfaces were exposed. The tubes were under observation at the moment the solution was added, and any immediate action noted; then the action during two hours was observed and finally observations were made at intervals of a day as long as peculiarities developed or changes took place.

An outline of these observations is given in tabular form along with a description of the metals employed.

1 A. Bannow, Ber. 7, 1498. 
The metals used are given below with notes as to the source and degree of purity of the samples.

\begin{tabular}{|c|c|c|c|}
\hline Sodium- & $\begin{array}{l}\text { Commercial product cut into } \\
\text { small pieces. }\end{array}$ & $\begin{array}{l}\text { Mercury- } \\
\text { Aluminum- }\end{array}$ & $\begin{array}{l}\text { Redistilled. } \\
\text { Sheet-Commercial. }\end{array}$ \\
\hline Potassium- & $\begin{array}{l}\text { Commercial product cut into } \\
\text { small pieces. }\end{array}$ & Tin- & $\begin{array}{l}\text { Powder-coarse. } \\
\text { Foil. }\end{array}$ \\
\hline Copper- & $\begin{array}{l}\text { Foil-Electrolytic C. P., for } \\
\text { analysis. } \\
\text { Wire-Commercial product. } \\
\text { Gauze-Pure, for analysis. } \\
\text { Powder-C. P., very pure. }\end{array}$ & Lead- & $\begin{array}{l}\text { Granular, E. and A., tested } \\
\text { purity. } \\
\text { Stick-C. P. } \\
\text { Filings-from the stick. } \\
\text { Sheet-Commercial product. }\end{array}$ \\
\hline Silver- & Sheet-Pure & Arsenic- & Coarse-E. and $A$. \\
\hline Torno-1 & $\begin{array}{l}\text {-Granular-(Powder)-Pure. } \\
\text { Ribbon-Commercial product. } \\
\text { Turnings-Commercial product. }\end{array}$ & $\begin{array}{l}\text { Antimony- } \\
\text { Bismuth- }\end{array}$ & $\begin{array}{l}\text { Powder. } \\
\text { Coarse-Merck. } \\
\text { Granular-Lumps } 98 \text { p. c. }\end{array}$ \\
\hline Zinc- & $\begin{array}{l}\text { Stick-C. P. } \\
\text { Granular-C. P. }\end{array}$ & Manganese- & $\begin{array}{l}\text { Powder-Merck highest purity. } \\
\text {-I,umps-Pure, fused. }\end{array}$ \\
\hline$n-$ & $\begin{array}{l}\text { Powder-C. P., arsenic free. } \\
\text { Dust-Commercial. } \\
\text { Stick. } \\
\text { Filings-from the stick. }\end{array}$ & Iron- & $\begin{array}{l}\text { Wire-Pure, for analysis. } \\
\text { Powder-97.1 per cent. Re- } \\
\text { duced by hydrogen. } \\
\text { Sheet. }\end{array}$ \\
\hline
\end{tabular}

Action of THE Hydrohalogens on the Metals.

GROUP I.

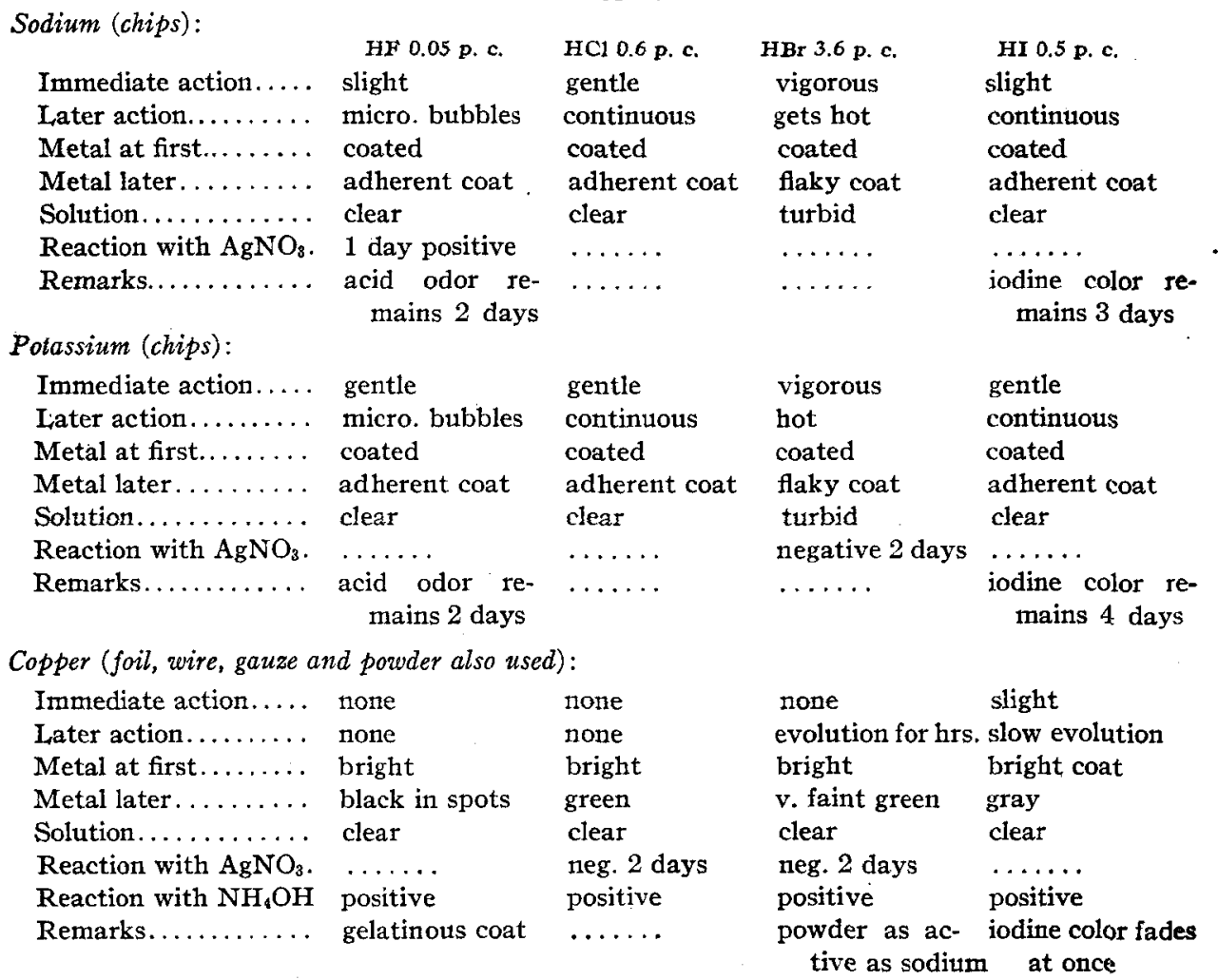




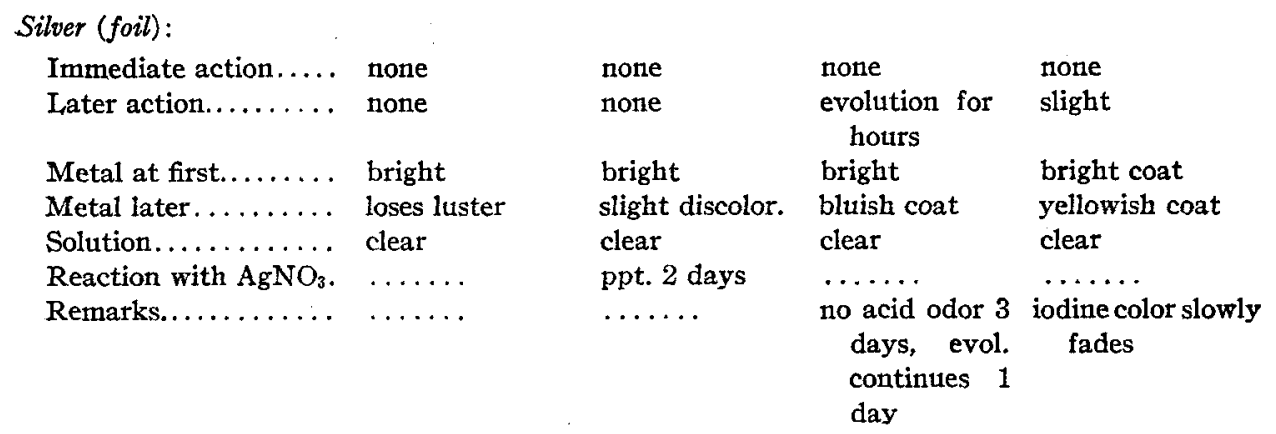

In the case of sodium and potassium each of the hydrohalogens caused immediate evolution of hydrogen. With hydrogen fluoride the activity decreased to a gentle continuous evolution of well-nigh microscopic bubbles, while with hydrogen bromide, the action was almost violent. The resulting bromide flaked off at once and the tube became hot. Perhaps the adherent coat of salt in the other case compelled a moderation of the action. The trace of iodine in the hydrogen iodide solution required several days for its complete removal, and pressed sodium only slowly removes the faint pink color due to the last traces of iodine as was noticed in the preliminary purification.

Of the copper and silver subgroup only hydrogen iodide and copper show an immediate evolution of hydrogen. In this case also the color of the iodine is almost instantly discharged. Hydrogen iodide causes a slight evolution of hydrogen with both metals, but with hydrogen bromide the action continues for hours. The pale coatings on the copper gradually develop a greenish color.

\section{GroUtP II.}

HF 0.05 p. c. $\quad \mathrm{HCl} 0.6$ p. c.

Magnesium (ribbon, turnings and powder also used):

\begin{tabular}{|c|c|c|}
\hline $\begin{array}{l}\text { Immediate action... . . } \\
\text { Later evolution... . . . }\end{array}$ & $\begin{array}{l}\text { none } \\
\text { none }\end{array}$ & $\begin{array}{l}\text { none } \\
\text { very gentle }\end{array}$ \\
\hline Metal at first......... & bright & bright \\
\hline Metal later. . . . . . . & slight discolor. & gray coat \\
\hline Solution........... & colorless & colorless \\
\hline Remarks......... & $\begin{array}{l}\text { powder v. slight } \\
\text { evol. }\end{array}$ & \\
\hline
\end{tabular}

Zinc (stick, powder, granular and dust):

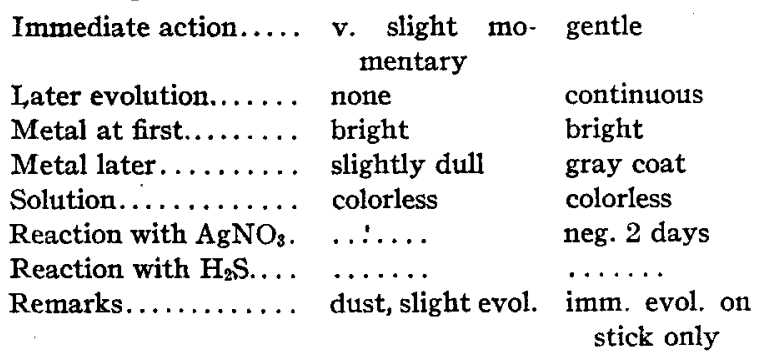

$$
\text { HBr } 3.6 \text { p.c. HI } 0.5 \text { p. c. }
$$

$\begin{array}{ll}\begin{array}{l}\text { slight } \\ \text { ceases after } 2\end{array} & \text { none } \\ \text { hrs. } & \text { none } \\ \text { bright } & \text { bright } \\ \begin{array}{c}\text { loses luster } 5 \\ \text { days }\end{array} & \text { gray coat } 3 \text { days } \\ \begin{array}{l}\text { colorless } \\ \text { soln. turbid }\end{array} & \begin{array}{l}\text { resin spots brown } \\ \text { iodine color fades } \\ \text { soln. clear }\end{array}\end{array}$

\begin{tabular}{|c|c|}
\hline slight & slight \\
\hline $\begin{array}{l}\mathrm{v} \text {. slight } \\
\text { bright } \\
\text { deposit } \\
\text { colorless }\end{array}$ & $\begin{array}{l}\mathrm{v} \text {. faint for hrs. } \\
\text { bright } \\
\text { white coat } \\
\text { colorless }\end{array}$ \\
\hline neg. 2 days & $\ldots \ldots$ \\
\hline $\begin{array}{l}\text { red spots on } \\
\text { metal }\end{array}$ & $\begin{array}{l}\text { none } \\
\text { color purple, } \\
\text { fades in one } \\
\text { day }\end{array}$ \\
\hline
\end{tabular}




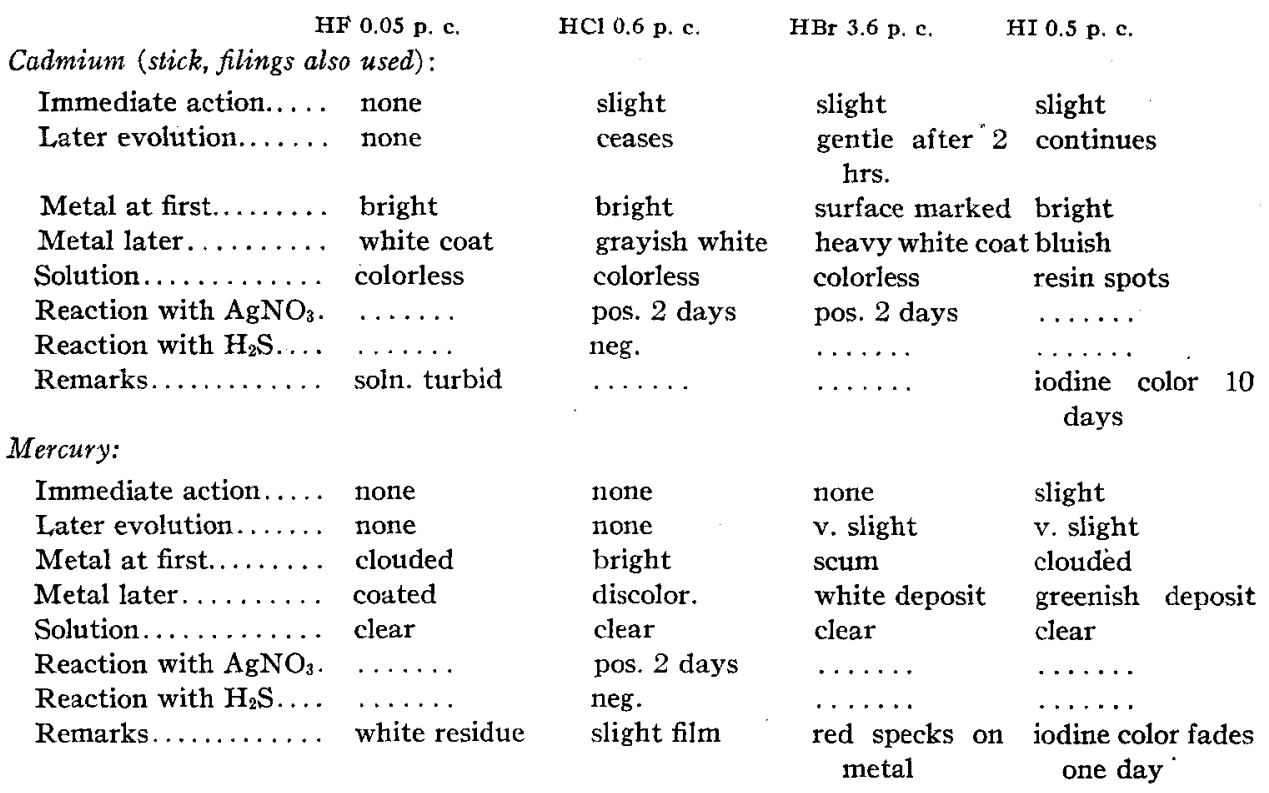

The only metal tried giving immediate evolution with each acid is zinc. The freshly broken stick with riewly exposed crystal faces is the only form of metal giving immediate evolution with hydrogen chloride. With hydrogen fluoride the momentary action ceased abruptly. Magnesium gives no perceptible evolution with hydrogen fluoride and iodide, but when the metal touches a resin spot a lively action ensues. These spots finally disappear and the solution remains clear. The faint iodine color in the cadmium solution is not discharged at all. Mercury reacts with each apparently; but only with hydrogen bromide and iodide is the evolution of gas perceptible and in the latter case immediate.

\begin{tabular}{|c|c|c|c|c|}
\hline Aluminum (sheet, powder & $\begin{array}{l}\text { HF } 0.05 \text { p. c. } \\
\text { also used): }\end{array}$ & $\begin{array}{l}\text { ROUP III. } \\
\text { HCl } 0.6 \text { p. c. }\end{array}$ & $\mathrm{HBr} 3.6 \mathrm{p} . \mathrm{c}$. & HI 0.5 p.c. \\
\hline Immediate action..... & none & none & slight & none \\
\hline Later evolution....... & none & none & ceased 2 hrs. & none \\
\hline Metal at first....... & bright & bright & bright & bright \\
\hline Metal later. . . . . . . & loses luster & dull & red discolor. & black \\
\hline Solution .......... & clear & clear & clear & $\begin{array}{l}\text { resin spots black } \\
\text { deposit }\end{array}$ \\
\hline Reaction with $\mathrm{AgNO}_{3}$. & & negative & $\ldots \ldots$ & $\ldots \ldots$ \\
\hline Remarks........... & $\begin{array}{l}\text { powder swells, } \\
\text { stain at bot- } \\
\text { tom }\end{array}$ & $\ldots \ldots$ & $\ldots \ldots$ & $\begin{array}{l}\text { iodine color } v \text {. } \\
\text { intense, fades } \\
\text { in } 5 \text { days }\end{array}$ \\
\hline
\end{tabular}

Aluminum only was tried. Hydrogen bromide gave an immediate evolution of gas which soon ceased. The metal slowly loses its luster, behaving about as magnesium. With hydrogen iodide the iodine color becomes intense at once and fades in the course of a day or so, but the metal turns black and a heavy black turbidity results. 
Group IV.

Tin (foil, granular also used):

HF 0.05 p.c. $\quad \mathrm{HCl} 0.6$ p.c. $\quad \mathrm{HBr} 3.6$ p.c. $\quad \mathrm{HI} 0.5$ p.c.

\begin{tabular}{|c|c|c|c|c|}
\hline Immediate action..... & none & none & slight & slight \\
\hline Later evolution....... & none & gentle & ceases 2 hrs. & v. faint \\
\hline Metal at first........ & bright & loses luster & loses luster & greenish coat \\
\hline Metal later. . . . . . . & blackens & coated & gray coat & brownish coat \\
\hline Solution . . . . . . . . & $\begin{array}{l}\text { slight turbidity } \\
\text { on glass }\end{array}$ & clear & clear & $\begin{array}{l}\text { faint brown, fi- } \\
\text { nally } v \text {. yellow }\end{array}$ \\
\hline Reaction with $\mathrm{AgNO}_{3}$. & & pos. & & pos. \\
\hline Reaction with $\mathrm{H}_{2} \mathrm{~S}$... & & neg. & $\ldots \ldots$ & neg. after 4 days \\
\hline Remarks.......... & & $\ldots \ldots$ & $\begin{array}{l}\text { granular; ac- } \\
\text { tion vigorous, } \\
\text { continuous }\end{array}$ & $\begin{array}{l}\text { iodine color fades } \\
\text { at once }\end{array}$ \\
\hline
\end{tabular}

Lead (stick, filings and sheet):

\begin{tabular}{|c|c|c|c|c|}
\hline $\begin{array}{l}\text { Immediate action..... } \\
\text { Later evolution...... }\end{array}$ & $\begin{array}{l}\text { none } \\
\text { none }\end{array}$ & $\begin{array}{l}\text { v. soon } \\
\text { rather gentle }\end{array}$ & $\begin{array}{l}\text { slight } \\
\text { v. faint }\end{array}$ & $\begin{array}{l}\text { slight } \\
\text { v. faint after } 1 \\
\text { day }\end{array}$ \\
\hline Metal at first. . . . . . . & bright & bright & white deposit & coated \\
\hline Metal later......... & blue coat & bluish gray & white crust & yellow crust \\
\hline Solution........... & turbid & clear & clear & brown stains \\
\hline Reaction with $\mathrm{AgNO}_{3}$. & . & pos. 2 days & pos. 2 days & $\ldots \ldots$ \\
\hline Reaction with $\mathrm{H}_{2} \mathrm{~S} \ldots \ldots$ & $\ldots \ldots$ & & $\cdots \cdots$ & neg. \\
\hline Remarks........... & $\begin{array}{l}\text { ppt. form s } \\
\text { brown spots }\end{array}$ & $\ldots \ldots$ & $\begin{array}{l}\text { filings: action } \\
\text { vigorous }\end{array}$ & $\begin{array}{l}\text { purple color } 10 \\
\text { days }\end{array}$ \\
\hline
\end{tabular}

Only hydrogen fluoride fails to carse perceptible evolution of gas. With hydrogen bromide and iodide the action on tin and lead is instantaneous; with hydrogen chloride they give a continuous evolution of gas. The halides coat the metals except in the case of tin, the yellow iodide solution of which gives a positive reaction with silver nitrate but not with hydrogen sulphide. With finely divided metals the action with hydrogen bromide is vigorous.

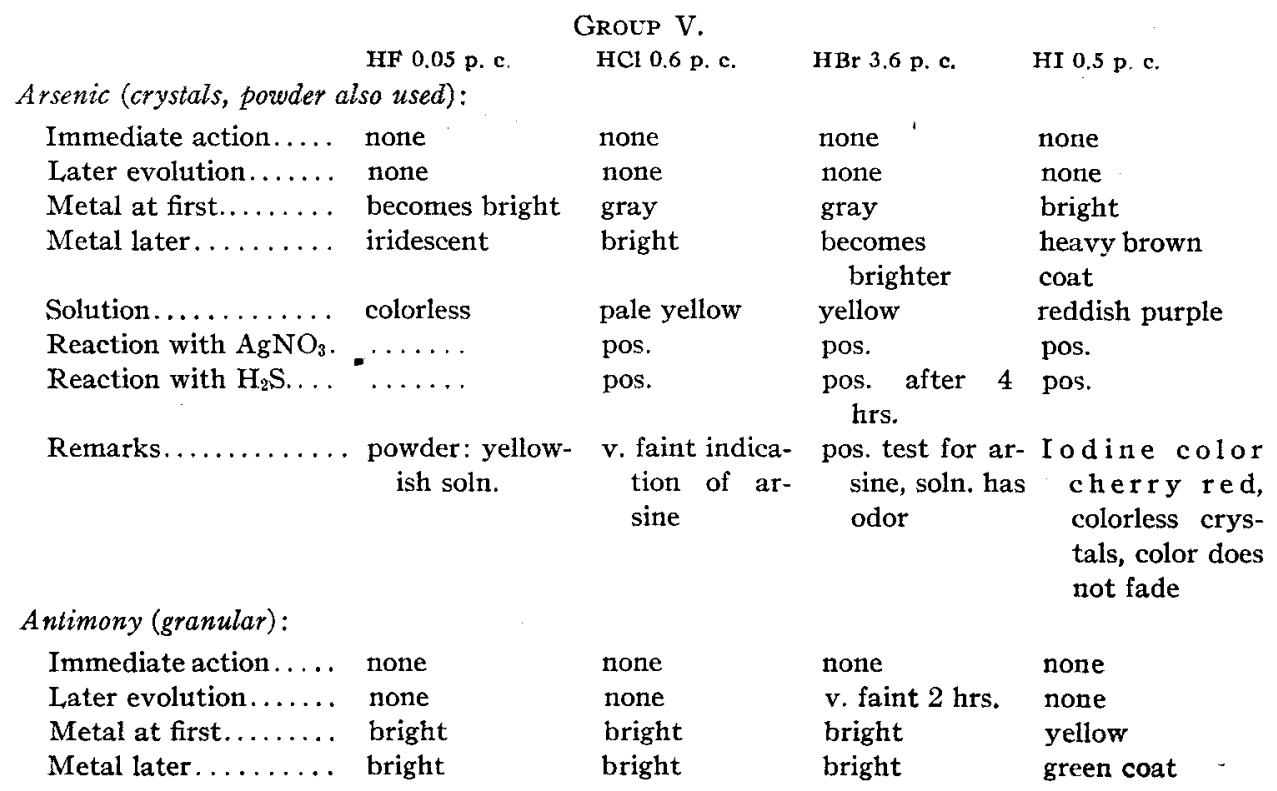




\begin{tabular}{|c|c|c|c|c|}
\hline Solution............ & $\begin{array}{l}\text { HF } 0.05 \text { p. c. } \\
\text { clear }\end{array}$ & $\begin{array}{l}\mathrm{HCl} 0.6 \text { p. c. } \\
\text { feathery crys- } \\
\text { tals }\end{array}$ & $\begin{array}{l}\text { HBr } 3.6 \text { p. c. } \\
\text { crystals }\end{array}$ & $\begin{array}{l}\text { HI } 0.5 \text { p. c. } \\
\text { green stain }\end{array}$ \\
\hline Reaction with $\mathrm{AgNO}_{3}$. & & pos. & & \\
\hline $\begin{array}{l}\text { Reaction with } \mathrm{H}_{2} \mathrm{~S} \ldots . . \\
\text { Remarks........... }\end{array}$ & $\begin{array}{l}\ldots \ldots \ldots \\
\text { soln. turbid }\end{array}$ & $\begin{array}{l}\text { pos. } \\
\text { slight indica- } \\
\text { tion of sti- } \\
\text { bine }\end{array}$ & $\begin{array}{l}\text { distinct odor } \\
\text { for stibine. } \\
\text { Crystals de- } \\
\text { posit }\end{array}$ & $\begin{array}{l}\text { red spots, yellow } \\
\text { deposit, iodine } \\
\text { color fades at } \\
\text { once }\end{array}$ \\
\hline \multicolumn{5}{|c|}{ Bismuth (granular, pulverized also used): } \\
\hline Immediate action. ... & none & none & none & none \\
\hline Later evolution....... & none & none & none & v. faint \\
\hline Metal at first........ & coated & bright & bright & red spots \\
\hline Metal later.......... & white coat & dull & greenish & blue coat \\
\hline Solution............ & turbidity on glass & crystals & purple discolor. & $\begin{array}{l}\text { greenish stain } \\
\text { colorless soln. }\end{array}$ \\
\hline Reaction with $\mathrm{AgNO}_{3}$. & & pos. & ....... & $\ldots \ldots$ \\
\hline Reaction with $\mathrm{H}_{2} \mathrm{~S} \ldots$ & $\cdots$ & & & \\
\hline Remarks............ & deposit & $\begin{array}{l}\text { needle crystals, } \\
\text { metal ce- } \\
\text { ments }\end{array}$ & $\begin{array}{l}\text { soln. contains } \\
\text { acid after } 5 \\
\text { days }\end{array}$ & $\begin{array}{l}\text { crystals in and } \\
\text { out of liquid, } \\
\text { resin spots re- } \\
\text { mained }\end{array}$ \\
\hline
\end{tabular}

The metals of this group, which were tried, react readily; but only in two cases, with antimony and hydrogen bromide, also with bismuth and hydrogen iodide, was there a perceptible evolution, and in no case' was gas instantaneously given off. However, on standing crystals appeared in several cases and tests for arsine and stibine gave positive results.

Arsenic gave tests with hydrogen sulphide after a few minutes and the powdered metal absorbed the acid in a very short time. The fluoride gave a yellow solution and no reaction with hydrogen sulphide; while with the other halides all gave tests with hydrogen sulphide and silver nitrate. In the hydrogen iodide solution colorless crystals appeared on the walls of the tube. Bismuth caused a faint evolution only with the iodide and this was not immediate. In every case the metal was acted upon. With the fluoride, the tube became coated and a deposit formed. The acidity of the bromide solution was not discharged for several days. However, the metal became covered with a green coat and the solution had a greenish appearance. The chloride and iodide formed needle-like crystals which appeared both outside the solution and in it. The metal became adherent in the case of the chloride and assumed a beautiful blue color with red spots. The crystals in the iodide solution were red, while the solution remained colorless. Hydrogen sulphide gave no reaction.

\begin{tabular}{|c|c|c|c|c|}
\hline Tanganese (lumps): & HF 0.05 p. c. & $\begin{array}{l}\text { ROUP VII. } \\
\text { HCl } 0.6 \text { p. c. }\end{array}$ & $\mathrm{HBr} 3.6$ p. c. & HI 0.5 p. c. \\
\hline Immediate action..... & none & none & slight & v. slight \\
\hline Later evolution........ & none & none & ceases soon & continues weakly \\
\hline Metal at first... & bright & bright & bright & bright \\
\hline $\begin{array}{l}\text { Metal later } \ldots \ldots \ldots \ldots \\
\text { Solution. } \ldots \ldots \ldots \ldots \ldots\end{array}$ & $\begin{array}{l}\text { white coat } \\
\text { colorless }\end{array}$ & $\begin{array}{l}\text { loses luster } \\
\text { colorless }\end{array}$ & $\begin{array}{l}\text { loses luster } \\
\text { yellowish }\end{array}$ & $\begin{array}{l}\text { heavy brown coat } \\
\text { resin spots }\end{array}$ \\
\hline $\begin{array}{l}\text { Reaction with } \mathrm{AgNO}_{8} . \\
\text { Remarks............ }\end{array}$ & $\begin{array}{l}\text { soln. slightly tur } \\
\text { bid }\end{array}$ & neg. 2 days & $\begin{array}{l}\ldots \ldots \\
\text { coat swells }\end{array}$ & $\begin{array}{l}\text { iodine color } \\
\text { deepens, fades } \\
\text { in } 3 \text { days }\end{array}$ \\
\hline
\end{tabular}


The hydrogen bromide and iodide show a slight immediate action on manganese. The physical appearance of the metal alters and where much action has taken place a brownish coat forms which is rather bulky. With the iodide the iodine color becomes very intense and then fades away.

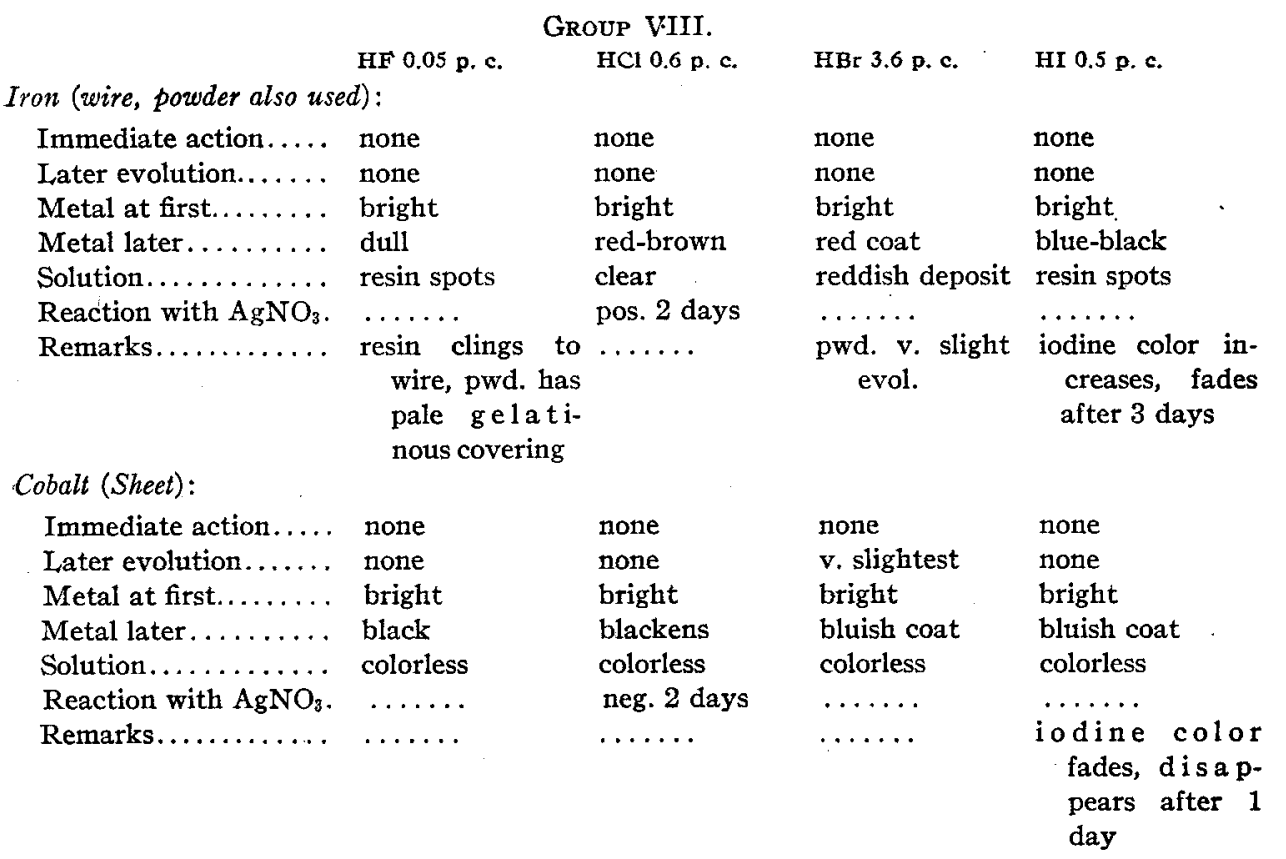

In no case tested was there immediate evolution of hydrogen and only the action of the hydrogen bromide on cobalt was seen to yield any hydrogen. Iron becomes coated and the solutions slightly discolored but no positive tests for the metal or halides were obtained. With the fluoride, iron powder becomes covered with a gelatinous layer, very pale in color.

SUMMARY.

Hydrogen fluoride of 0.05 p. c. strength reacts with metals of the first group with evolution of hydrogen and formation of adherent coats. However, the action on silver and copper is somewhat uncertain. With those metals of the second group that were tested there is apparently no immediate action. Slight turbidities appear only after considerable time. The powdered forms of magnesium and zinc disengaged bubbles which had been simply included, perhaps. Aluminum was the only representative of Group III tried. No immediate action was perceptible, but the powder swelled in a most peculiar manner. Tin and lead became darkened on the surface and a turbidity and precipitate appeared in the solution. The elements of the fifth group also react. The concentration of the hydrohalogen is rather low to give well-characterized actions. The action on manganese, also that on iron and cobalt, seem to be slight.

Hydrogen chloride of 0.5 p. c. strength reacts with the alkali metals of the first group with continuous evolution of hydrogen. Both copper and silver are also acted upon but without visible liberation of hydrogen. Of the metals of the 
second group tested only mercury is so slowly acted upon that no gas appears, and a film forms on its surface. Tin and lead give a gentle but not immediate evolution. Arsenic, antimony and bismuth show no evolution of hydrogen but the elements go into solution as shown by the hydrogen sulphide test. With silver nitrate the formation of the hydrides was indicated.

Hydrogen bromide of 3.6 p. c. strength causes a vigorous immediate evolution with sodium and potassium and with the granular forms of tin and lead. The action is not immediate with mercury, nor with iron and cobalt, the members of the eighth group. With every other group slight evolution takes place, except, as stated, in the fifth where hydrides are formed.

Hydrogen iodide of 0.5 p. c. strength causes an evolution immediately with all the metals except silver, magnesium, aluminum and iron and cobalt also the elements of Group V. No evolution whatever takes place with magnesium, aluminum and iron and cobalt. Bismuth, in this case, only evolves a gas and crystals separate during the course of the reaction.

The fate of iodine is most interesting. The pink color remains for days in the presence of the alkali metals; also in the presence of lead, cadmium and aluminum, but is discharged at once by copper and fades slowly with silver. Magnesium, however, discharges the color gradually. In other cases the color becomes greatly intensified at first, due presumably to the dissociation or oxidation of hydrogen iodide. Zinc, aluminum, arsenic, manganese and iron intensify the original color. It is instantly discharged with copper, tin and antimony.

The observations here recorded and the conclusious drawn therefrom are but preliminary, as those of a first survey must inevitably be. Each experiment should be repeated more carefully and other elements should be included within the scope of experimentation.

\section{SOME CRITICISMS OF THE U. S. PHARMACOPOEIA.*}

BY C. B. JORDAN.

In preparing this paper on criticisms of the Pharmacopoeia, I am fully aware that it is much easier to criticize than it is to execute, and that in preparing a work as stupendous as the one criticized, it is practically impossible to avoid errors. Yet, we wish our "Bible of Pharmacy and Medicine" to be as nearly perfect as possible and therefore criticisms are invited.

We are not all of one mind, and it is well that we are not. All may not agree with some of the criticisms offered, but that is to be expected, and discussion of them is very welcome. Some of these criticisms which I will offer may appear trifling, yet to a constant user of the United States Pharmacopoeia, they will appear of sufficient moment to merit discussion.

I have endeavored to classify these criticisms, and will offer them under various headings.

First, Lack of Uniformity.-Not consistent in writing the formulas of the glycerophosphates. Under solution of sodium glycerophosphate, the formula is

* Read before Section on Education and Legislation, A. Ph. A., City of Washington meeting, 1920 . 